\title{
TOX3 wt Allele
}

National Cancer Institute

\section{Source}

National Cancer Institute. TOX3 wt Allele. NCI Thesaurus. Code C68711.

Human TOX3 wild-type allele is located in the vicinity of $16 q 12.1$ and is approximately 110 $\mathrm{kb}$ in length. This allele, which encodes TOX high mobility group box family member 3 protein, may play a role in the regulation of transcription. 